\title{
Coastal Pollution Management Plan in Odisha Coast
}

\author{
D. Anburaja, G. Sudharson, M. Kalpana, M.G. Prathap
}

\begin{abstract}
Odisha Coast originate from every land based totally totally or ocean primarily based completely wearing activities from issue assets, for example, mechanical launch, oil slick occurrences, circle of relatives sewage and non thing assets like agribusiness keep going for walks off. the ones pollution may additionally have an impact on seaside the the front water tremendous, marine residue situations and unique life office work sincerely as normal territories like mangrove, ocean grass and coral reefs. The massive motives for marine infection are population development rapid urbanization and industrialization.

Water excellent parameters for beach the the front waters of Odisha are fundamental to observe for distinguishing the crucial detail pollutants. Spatial styles of collection of physio-substance parameters, for example, Dissolved Oxygen (DO), suspended silt cognizance(SSC), chlorophyll-a, Nitrate (NO3), all out nitrogen and all out phosphorous(TP) had been completed making use of spatial interjection approach and incorporated with Land use/land cowl(LULC) maps. At ultimate optionally available subtleties of Odisha coast has been collected and contrasted and the accessible effects and prepared into cause pressure, pressure, state, impact and response (D-P-S-I-R), to find out the capability risks over the seaside natural device of Odisha.

the usage of composts has likewise multiplied severa folds over time body, bringing approximately the complement beautify of seaside waters of Odisha. aside from that, there's expanding waterfront disintegration and bodily video games like sand mining, extreme urbanization and this enlargement consists of infection weight in Odisha coast. From the GIS information based totally marine contamination look at for the shore of Odisha it's been comprehended that the Odisha coast is significantly impacted by the usage of anthropogenic carrying sports and want to be determined constantly as a "top hotspot" for higher management of these seaside waters.
\end{abstract} GIS

Catchphrases: water exceptional, LULC, pollution, DPSIR,

\section{PRESENTATION}

India has a coastline of 7,500 km and multiple,305,143 km special economic region (EEZ), which supports nearly $30 \%$ of its human populace. The marine state of affairs of Indian harbors has an collection of precise marine natural structures,

Revised Version Manuscript Received on 10, September 2019.

D. Anburaja, Assistant Professor, Department of Civil Engineering, Saveetha Engineering College, Thandalam, Chennai-602105. Tamil Nadu, India. (Email: anburaja@saveetha.ac.in)

G. Sudharson, Assistant Professor, Department of Civil Engineering, Saveetha Engineering College, Thandalam, Chennai-602105. Tamil Nadu, India.

M. Kalpana, Assistant Professor, Department of Civil Engineering, Saveetha Engineering College, Thandalam, Chennai-602105. Tamil Nadu, India.

M.G. Prathap, Associate Professor, Department of Civil Engineering, Saveetha Engineering College, Thandalam, Chennai-602105. Tamil Nadu, India. much like mangroves; coral reefs; salt lakes and dust pads. these environments, which essentially are the territories of jeopardized marine species and monetarily massive flowers. India keeps on being the 7th largest marine angling u.S. on the earth.

India's coast faces a extensive scope of problems, as an example, populace improvement, urbanization and industrialization. seaside the the front infection in India emerges basically from land-based totally actually property viz. Residential waste, cutting-edge-day effluents, farming spillover and unique assets, at the side of transportation wearing events, seaward investigations and misuse and infrastructural enhancements.

Marine contamination is a exchange of physical, compound and natural features of water and silt. It reasons debasement of the normal nature of the seaside the the front conditions. It influences the well being and staying electricity of all styles of existence. It is a good sized problem in developing international locations and the continuing examinations confirm that the styles are relied upon to increment. in this manner, there can be a want to recognize the critical anthropogenic carrying occasions affecting waterfront waters in conjunction with the maximum real pressure factors.

herbal infection is the most unavoidable organic emergency to which we're oppressed nowadays. it is because of the quick city-cutting-edge-day innovation unrest and non-low-cost misuse of ordinary property with the resource of a developing populace. in recent times the earth has have grown to be out to be defiled, undesirable, and consequently terrible for the steadiness of living creatures, which incorporates man. Be that as it is able to, the boundless voracious misuse of nature with the resource of guy has upset the sensitive environmental parity modern amongst dwelling and non-dwelling elements of the planet earth. This unwanted state of affairs made with the aid of man has undermined the persistence of guy himself and different residing biota on earth. The term contamination is characterised in top notch manners. as an example:

- pollutants is the growth of the additives to water, air, land, which unfavorably modify the normal nature of the earth.

- pollutants is the horrible rotation of our scenario, to a great extent due to human wearing sports activities.

- pollution implies the boom of any a ways flung fabric like inorganic, natural, natural or radiological or any bodily alternate happening within the nature, which may also 
moreover harm or effect residing existence bureaucracy legitimately or in a roundabout manner, fast or after pretty some time.

- pollutants is the presentation of surplus strength or waste hassle into the earth of guy's carrying sports, which legitimately or thru implication makes risk guy and his scenario.

\section{Results \& Discussions}

Odisha is positioned in the northeastern shore of India. it's far a sea nation with big capability in ordinary property. it is situated among $17^{\circ} 40$ nine' $\mathrm{N}$ and $22^{\circ} 34^{\prime} \mathrm{N}$ scopes and eighty one $^{\circ} 27^{\prime} \mathrm{E}$ and $87^{\circ} 29^{\prime} \mathrm{E}$ longitudes. Odisha nation covers a territory of $156,000 \mathrm{~km} 2$ and has an all out population of Odisha regular with 2011 data is $41,947,358$. The state has a population thickness of 236 people/km2 (2001 assessment) protecting 30 regions in conjunction with six beach the front locale, viz., Balasore, Bhadrak, Kendrapada, Jagatsinghpur, Puri, and Ganjam, traversing a coastline of $480 \mathrm{~km}$, decide 1 . The all out populace of those six waterfront areas is forty one,947,358 and is conveyed in a territory of $155,707 \mathrm{~km} 2$ with a populace thickness 269 people/km2 (2011 enumeration). The examination place has global importance and is one of the locales of worldwide legacy that attracts in sightseers and vacationers. it's miles Asia's biggest harsh water tidal pond, the Chilika; a $672 \mathrm{~km} 2$ huge mangrove timberland and wetland, the Bhitarkanika natural existence asylum. the world's largest known settling sea shores of Olive Ridley ocean turtles are likewise determined within the locales of Gahirmatha and Rushikulya. right right here are 10 reading focuses unfold at numerous separations over the Puri coast. Fig \#1 exhibit the research location of orissa.

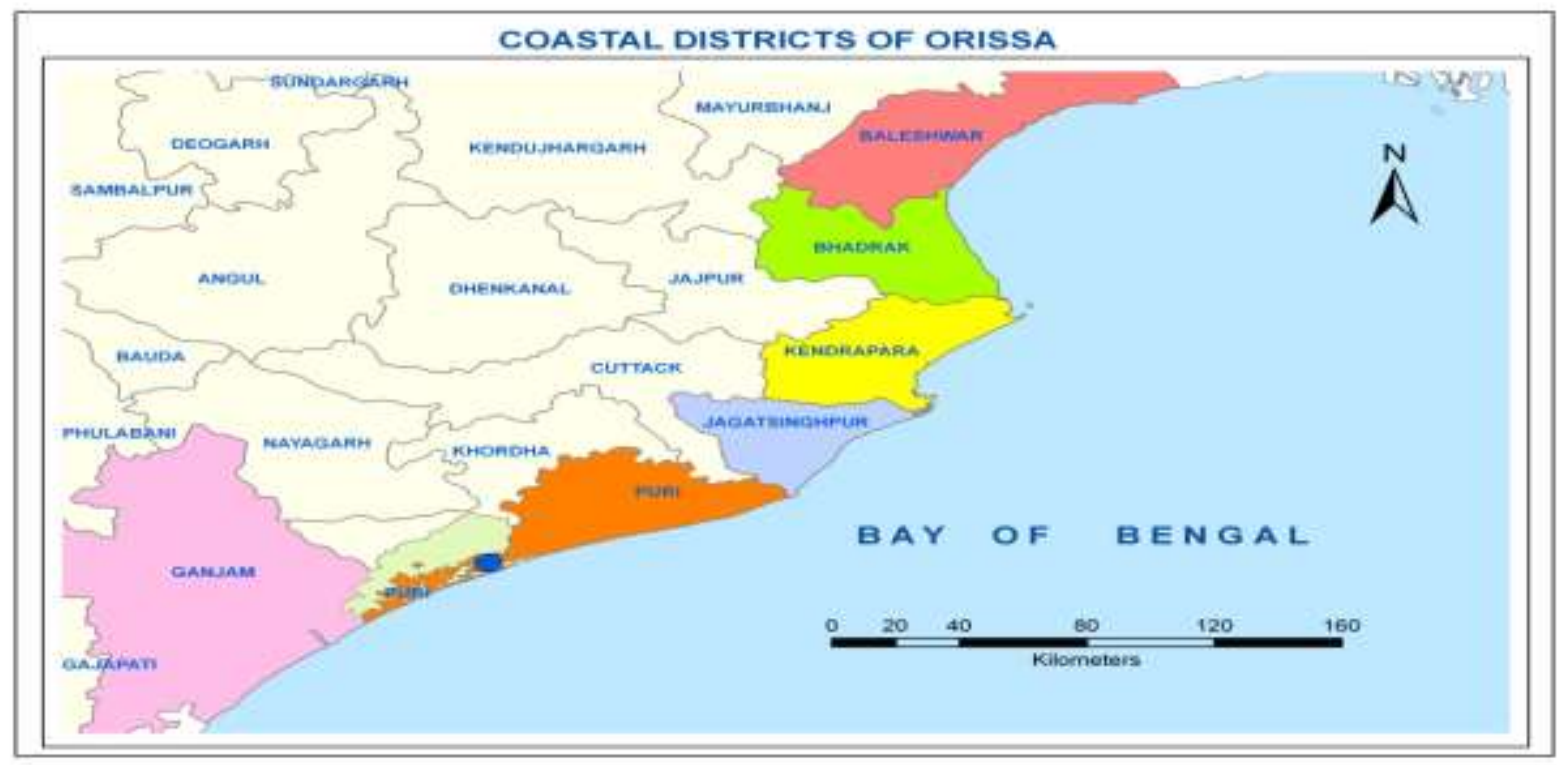

Figure 1: Study Area

\section{PHYSIOGRAPHY}

based on homogeneity, congruity and physiographical tendencies, Odisha has been isolated into 5 big locales:

- The waterfront fields in the east

- The middle sloping and real countries locale

- The focal levels

- The western transferring uplands, and

- The large flood fields

(deliver:

http://en.Wikipedia.Org/wiki/Geography_of_Odisha)

\section{TECHNIQUE}

The thing of this examination is to offer a GIS-primarily based database to translate the contamination degree inside the seashore waters of Odisha at the east financial institution of India. a couple of selected essential physico-concoction parameters, but more than one inorganic nutritional supplements were collected as an auxiliary facts. Auxiliary records deliver is integrated Coastal and Marine vicinity management assignment Directorate (ICMAM-PD) at some point of 2007.

1. Suspended Sediment attention (SSC)

2. stylish Nitrogen (TN)
3. Dissolved Oxygen (DO)

4. regular Phosphorous (TP)

5. Chlorophyll-a

all the above parameters and are uncovered to dynamic adjustments in behavior due to each normal and anthropogenic variables, after a reputedly limitless amount of time after year. 


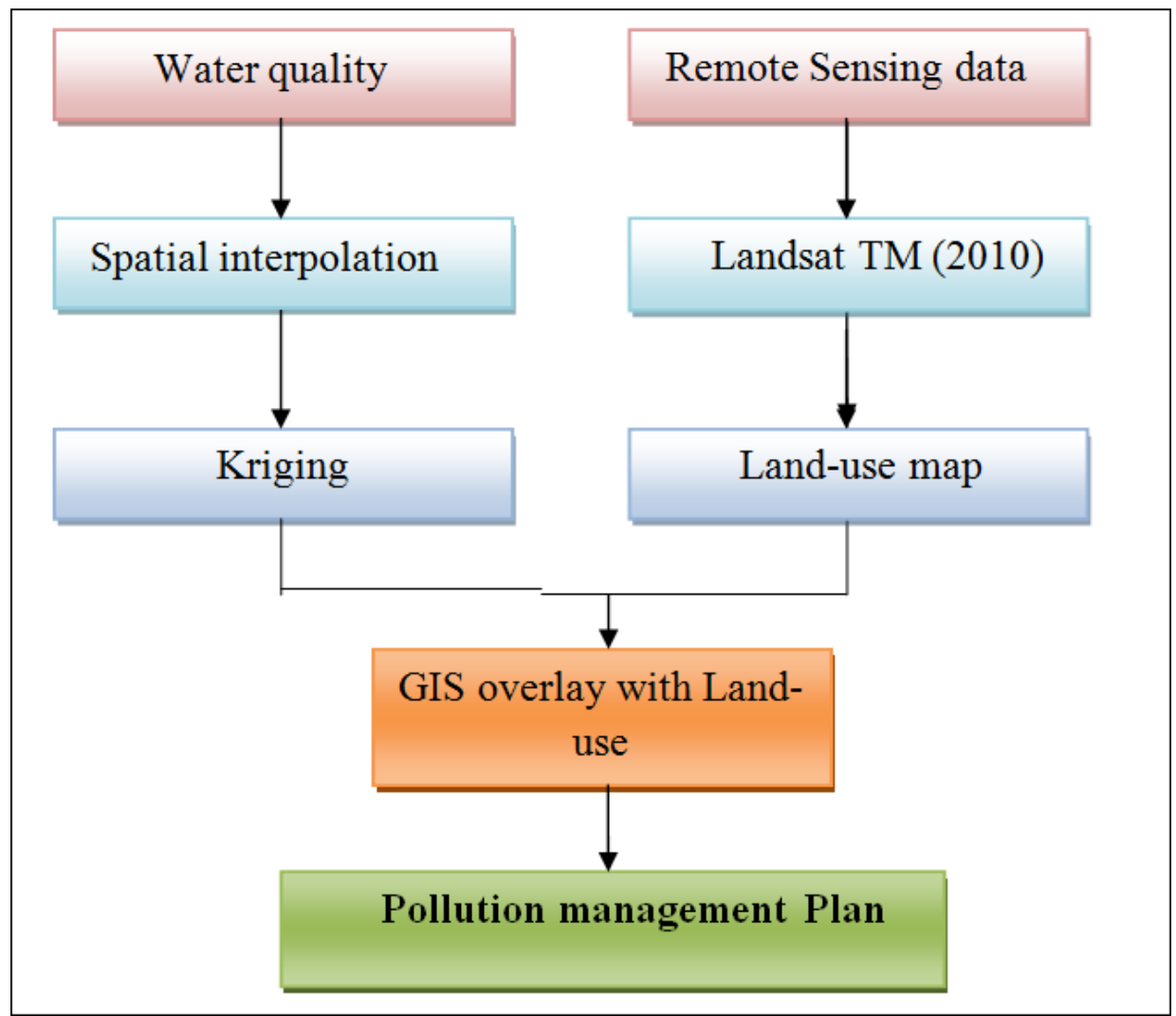

Methodology of the flow chart

\section{RESULTS \& DISCUSSION}

In this study, the results are presented and discussed in three parts:

1. Land use and land cover map for Odisha coast.

2. Spatial interpolation and interpretation of the secondary water quality data.

This would enable us to understand the basis behind the observed seasonal and spatial variability and the effects of land use characteristics on the coastal water quality data.

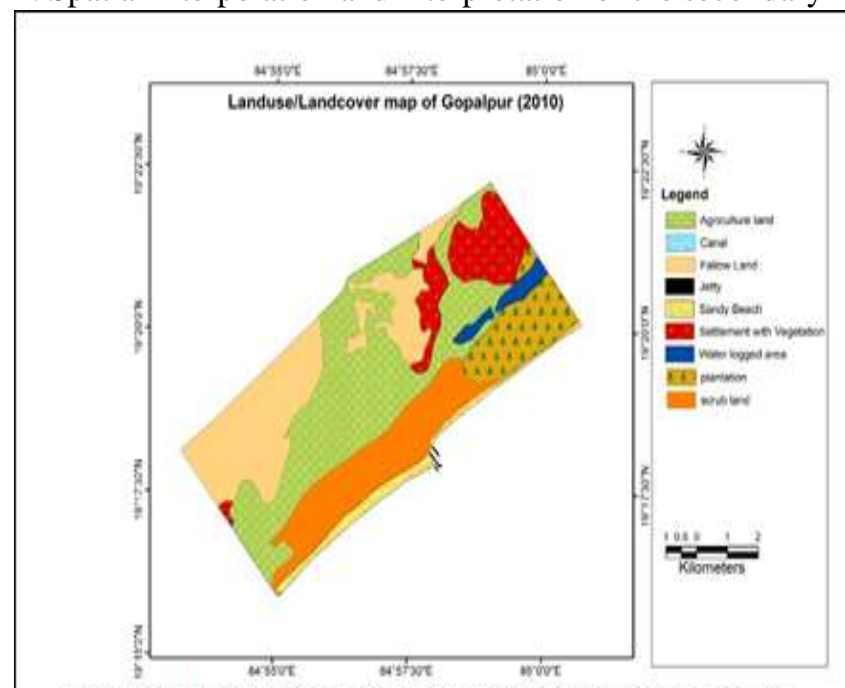

Coastalland use/land cover classes in Gopalpur

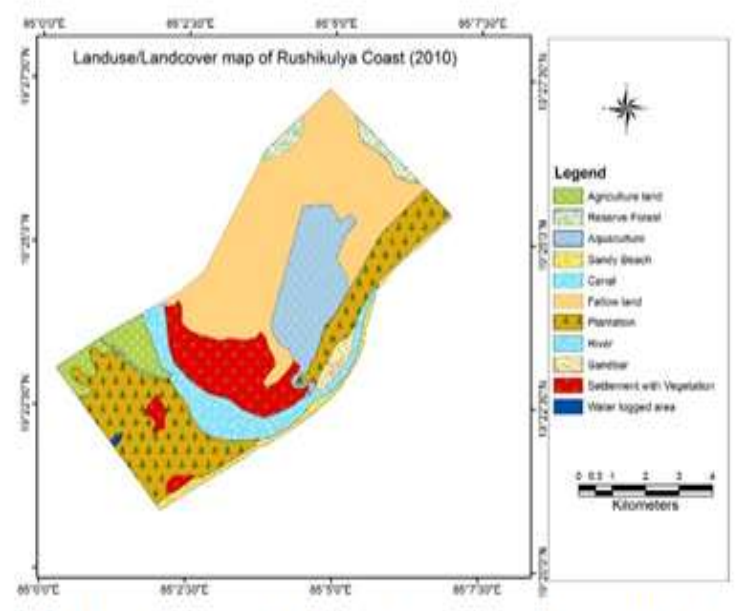

Coastal land use/land cover classes in Rushikulya 


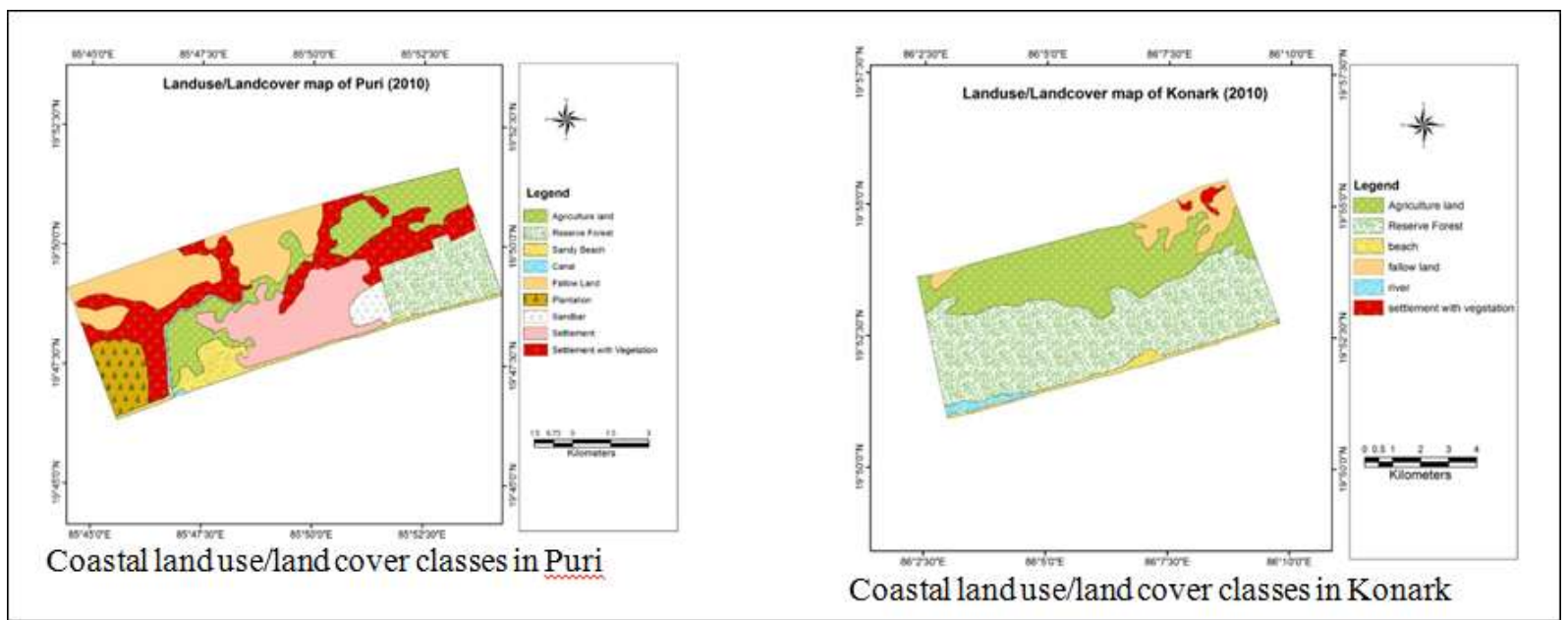

Gopalpur:

Variation in Chlorophyll-a (2007)

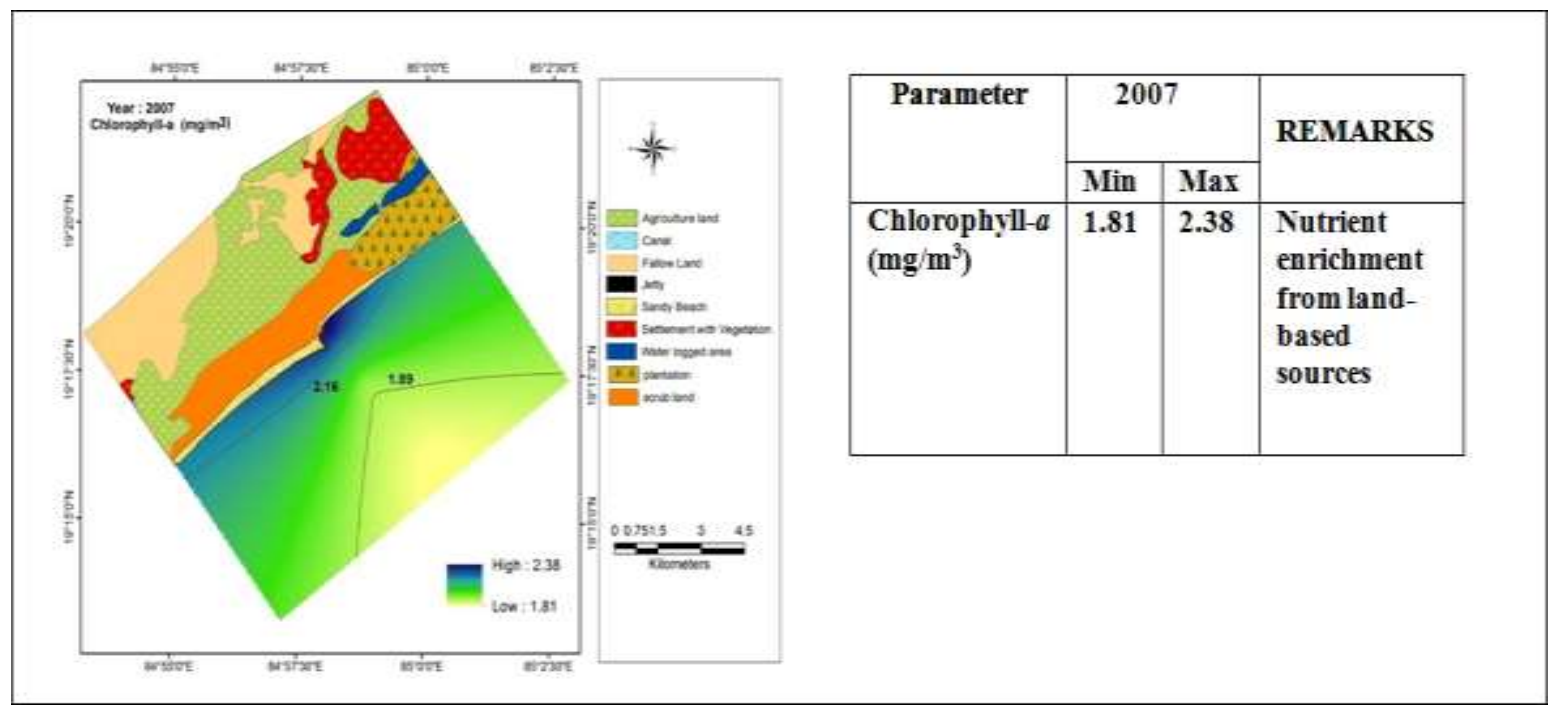

Variation in Dissolved Oxygen concentration (2007)

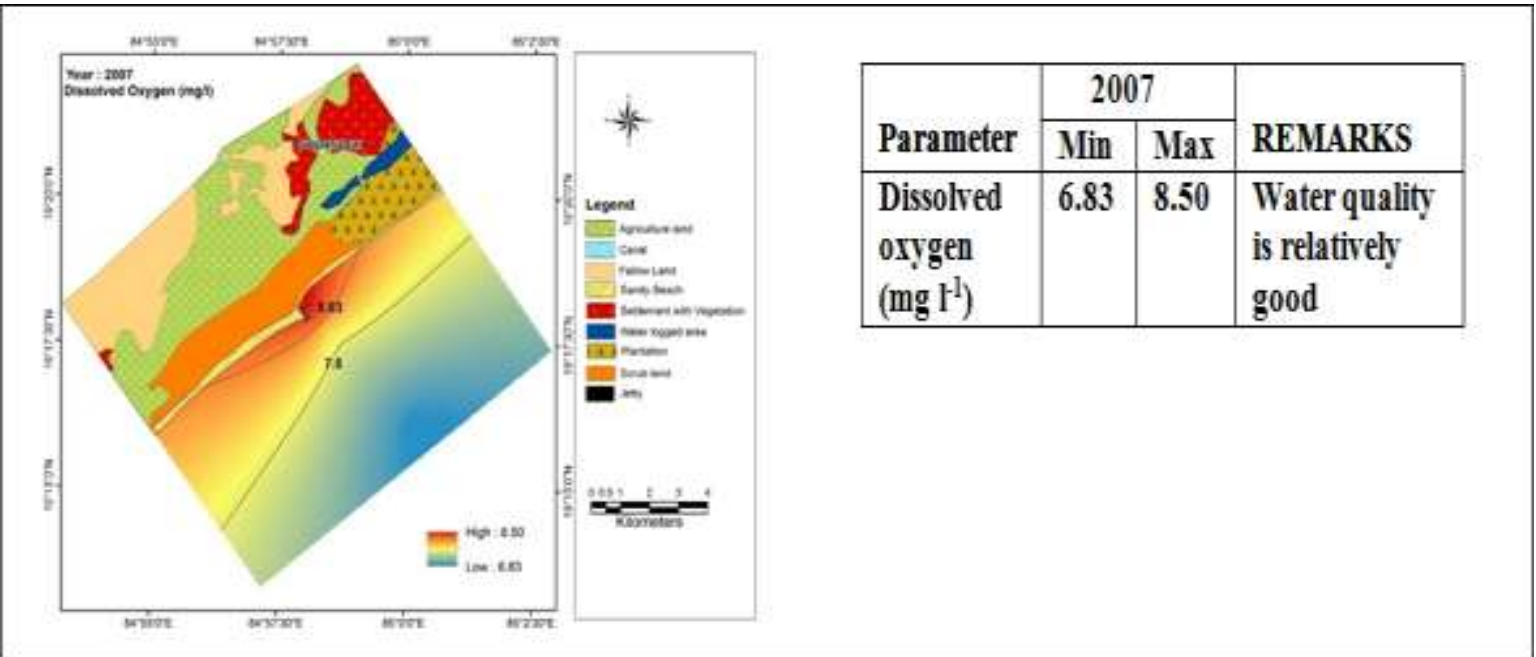

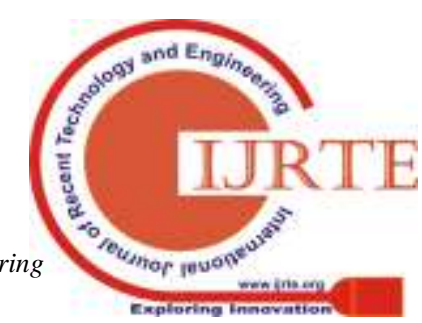


Variation in Suspended Solid Concentration (2007)

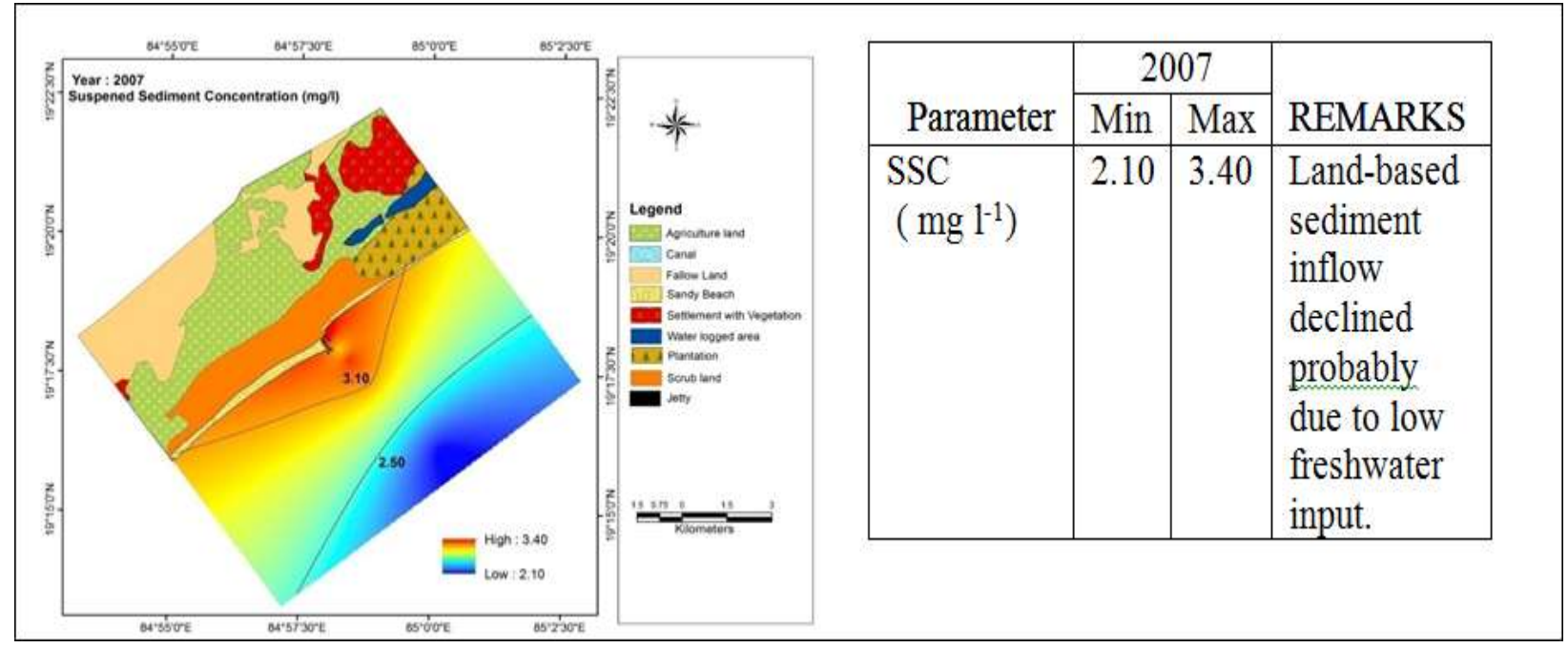

Variation in Total Nitrogen (2007)

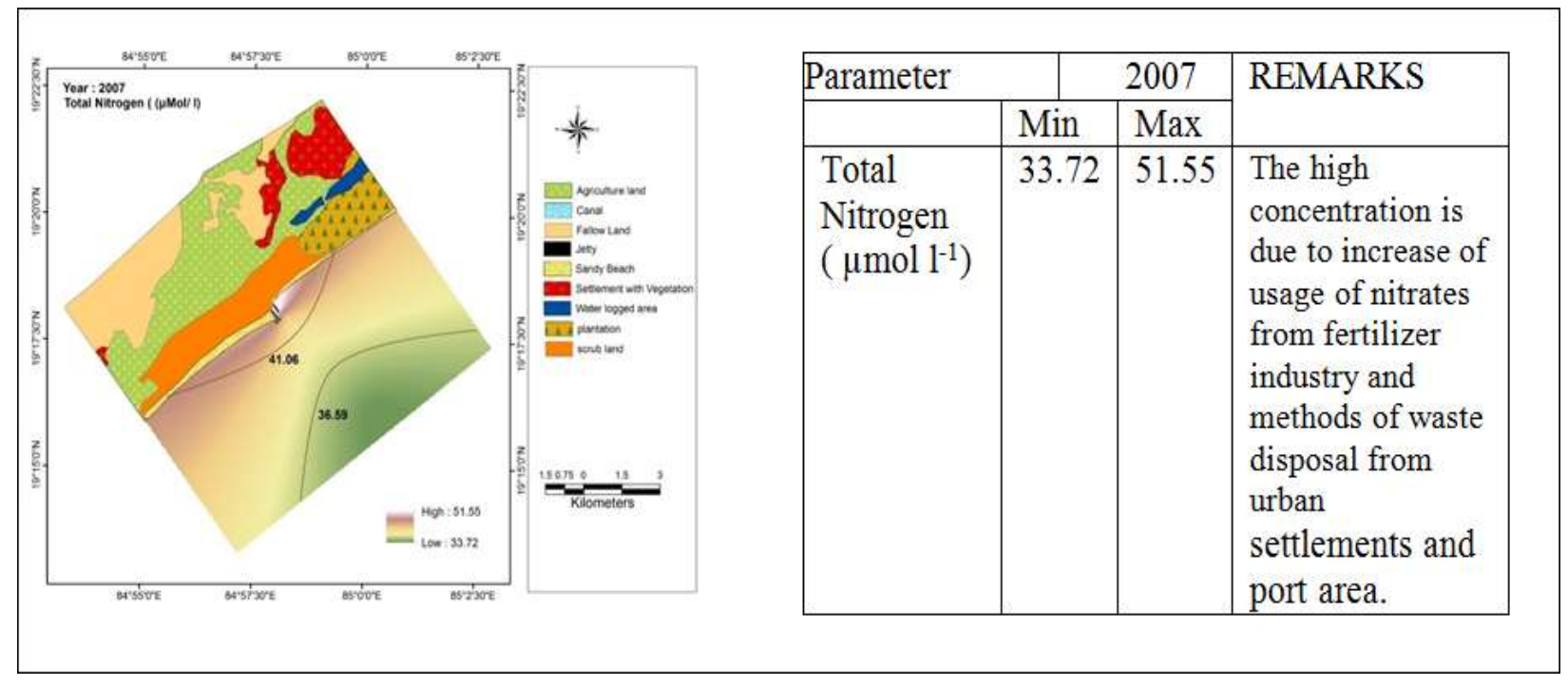

Variation in Total Phosphorus ( 2007)

\begin{tabular}{|l|l|l|l|l|}
\hline & Parameter & \multicolumn{2}{|c|}{2007} & \multicolumn{2}{|c|}{ REMARKS } \\
\cline { 3 - 5 } & Min & Max & \\
\cline { 4 - 6 } & $\begin{array}{l}\text { Total } \\
\text { Phosphorus } \\
\left(\mu \mathrm{mol1} 1^{-1}\right)\end{array}$ & 1.91 & 4.95 & $\begin{array}{l}\text { Abnormal values of Total } \\
\text { phosphorus (TP) were } \\
\text { observed near the Gopalpur } \\
\text { portjetty region. The possible } \\
\text { sources of TP in Gopalpur } \\
\text { Coastal Waters include, } \\
\text { Agricultural runoff, industrial } \\
\text { effluents, cargo handling like } \\
\text { fertilizers and detergents from } \\
\text { land-based runoff. }\end{array}$ \\
\hline
\end{tabular}


RUSHIKULYA:

Variation in Chlorophyll-a (2007)

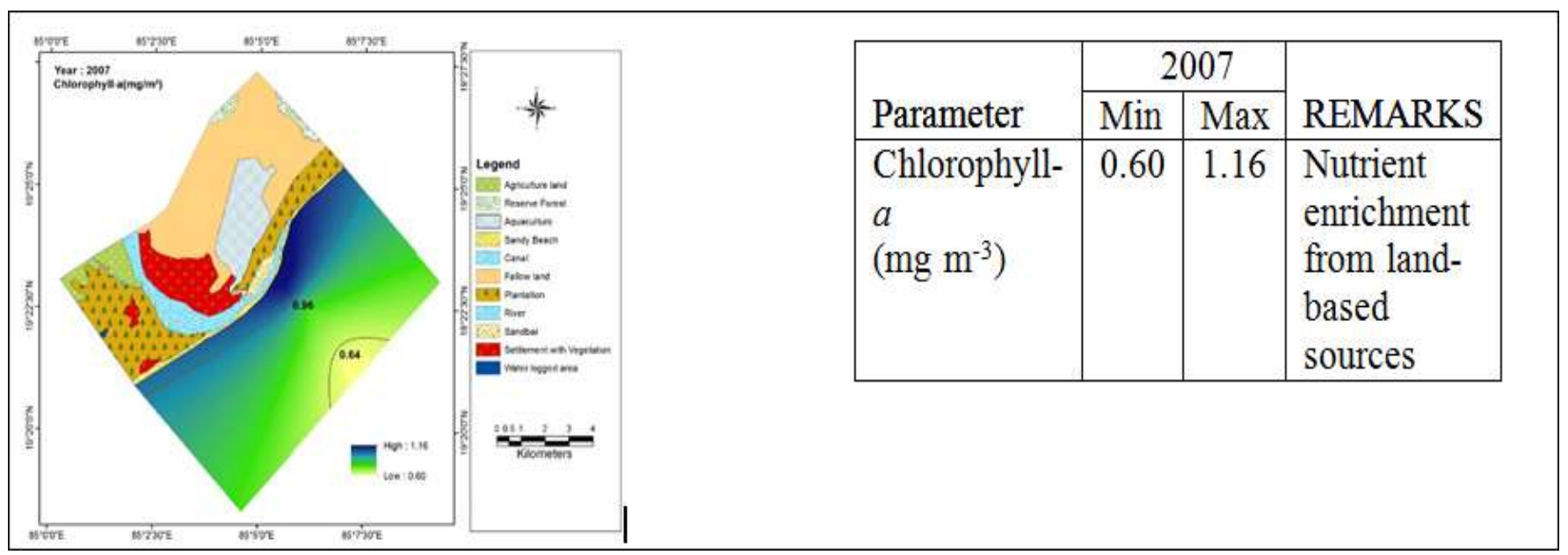

Variation in Dissolved Oxygen concentration ( 2007)

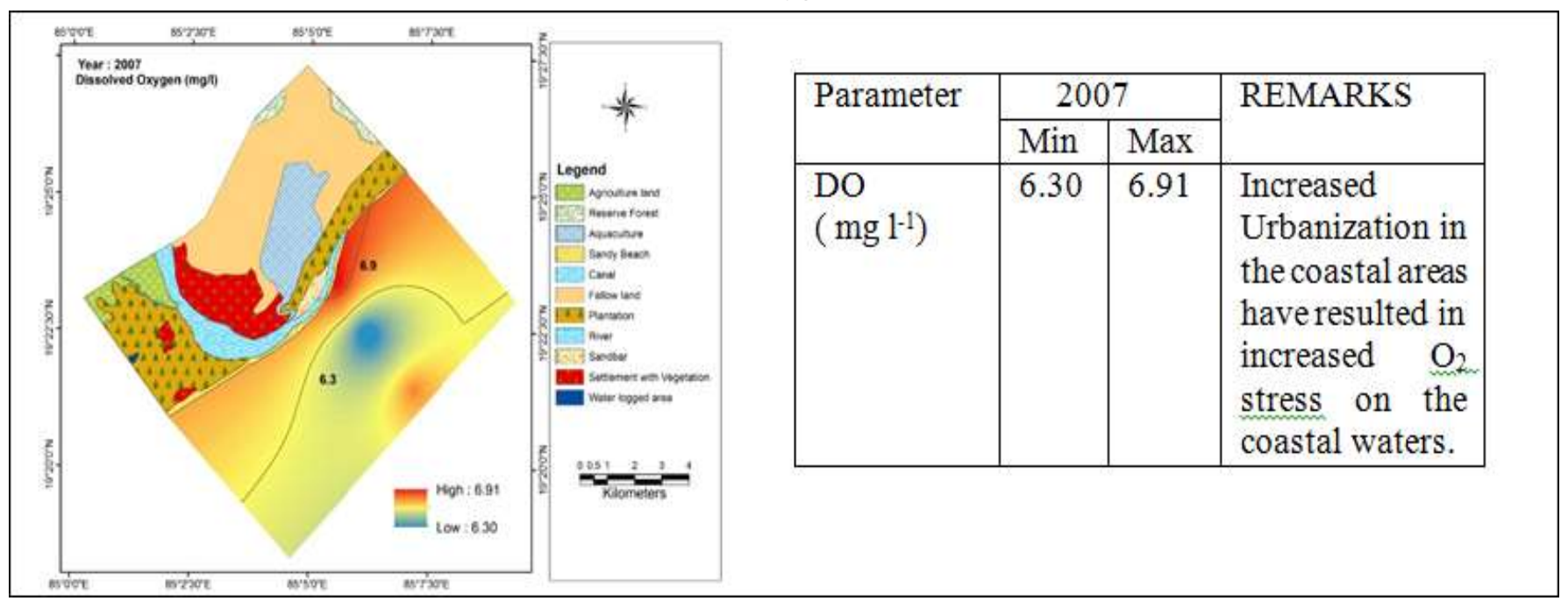

Variation in Suspended Solid Concentration (SSC) ( 2007)

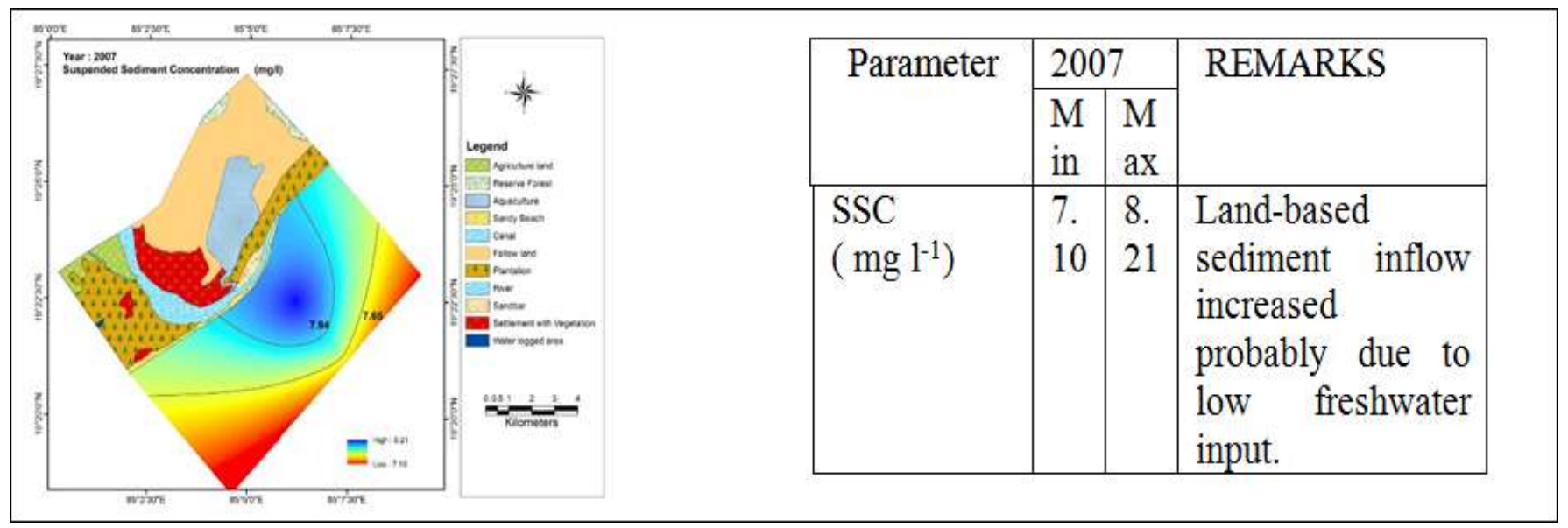


International Journal of Recent Technology and Engineering (IJRTE)

ISSN: 2277-3878, Volume-8, Issue-2S11, September 2019

Variation in Total Nitrogen (2007)

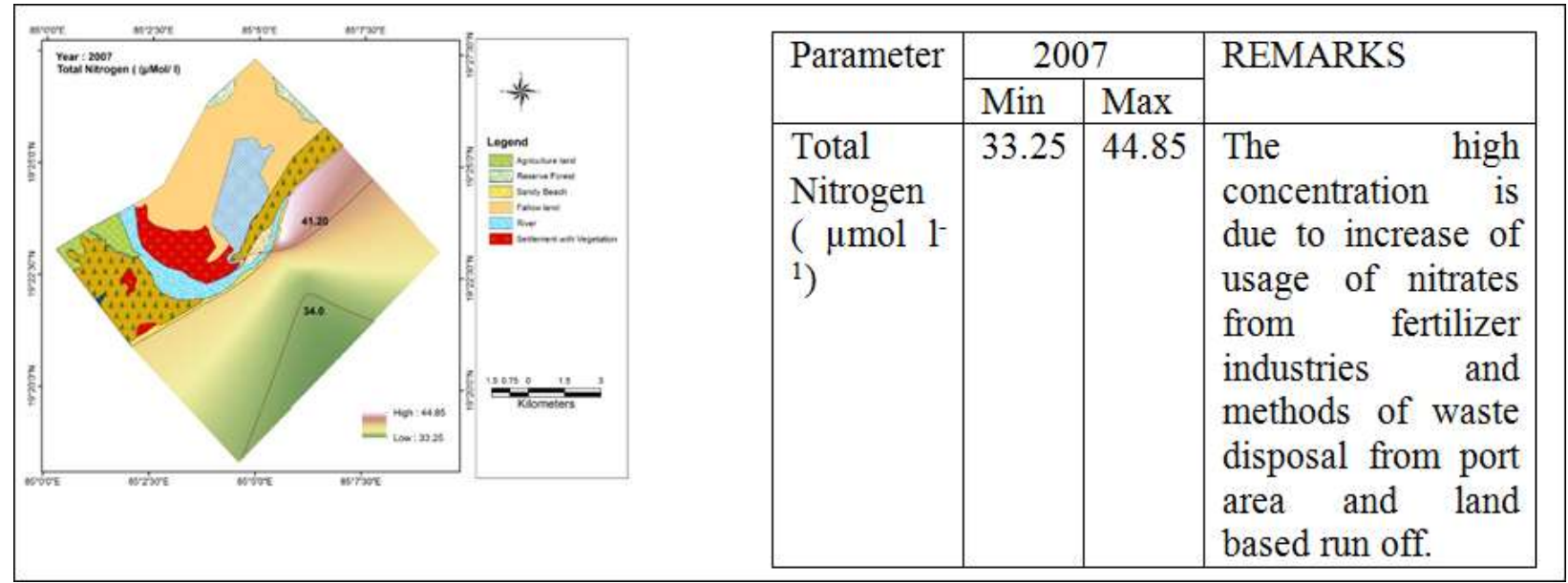

Variation in Total Phosphorus (2007)

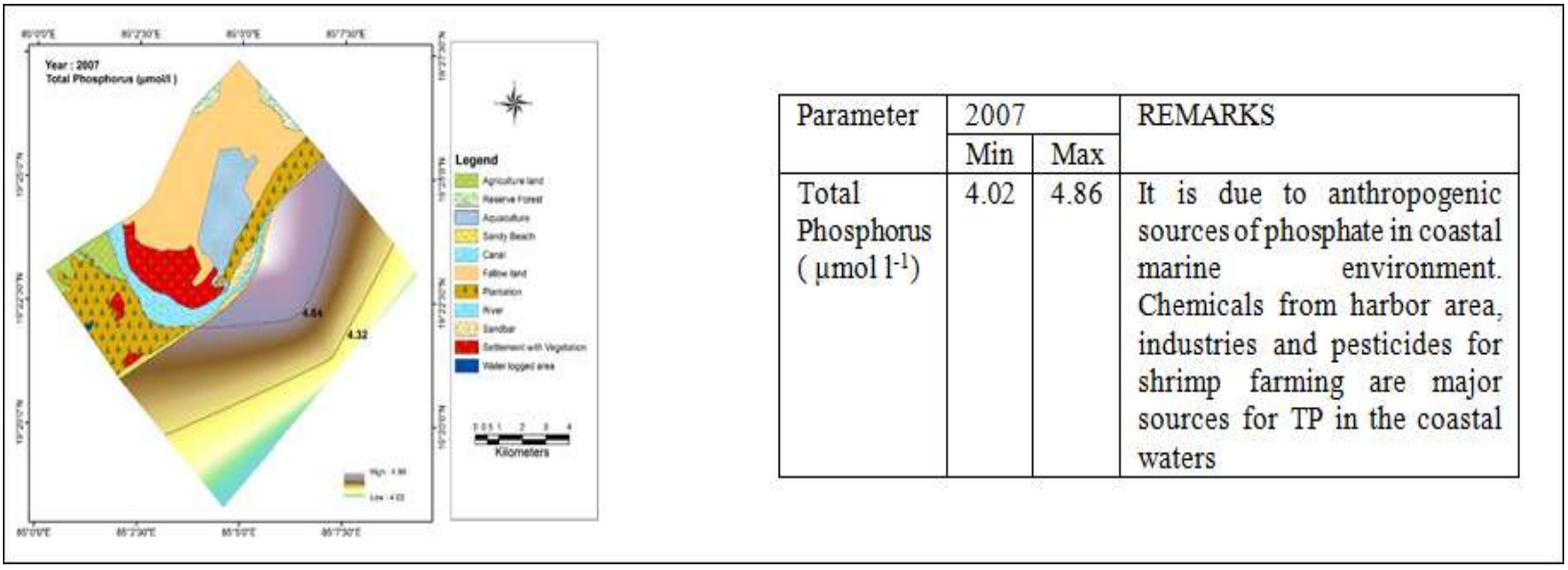

Puri

Variation in Chlorophyll-a (2007)

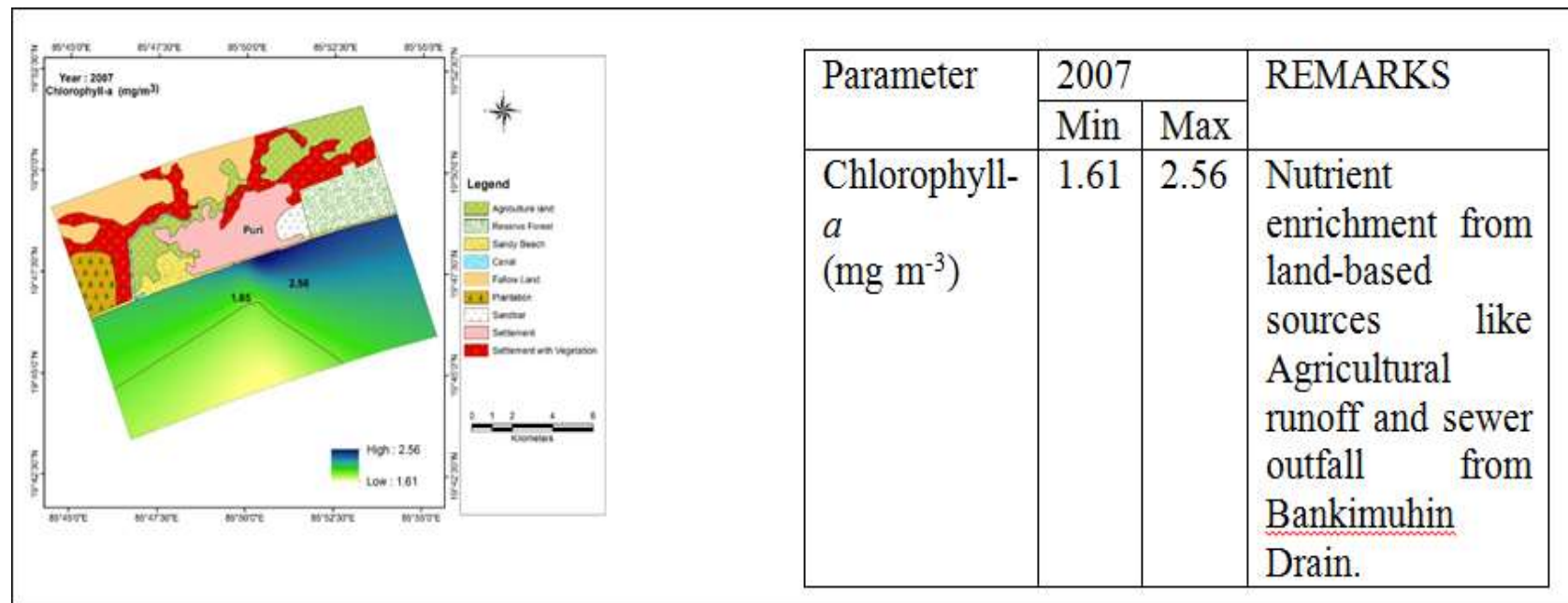


Variation in Dissolved Oxygen concentration (2007)

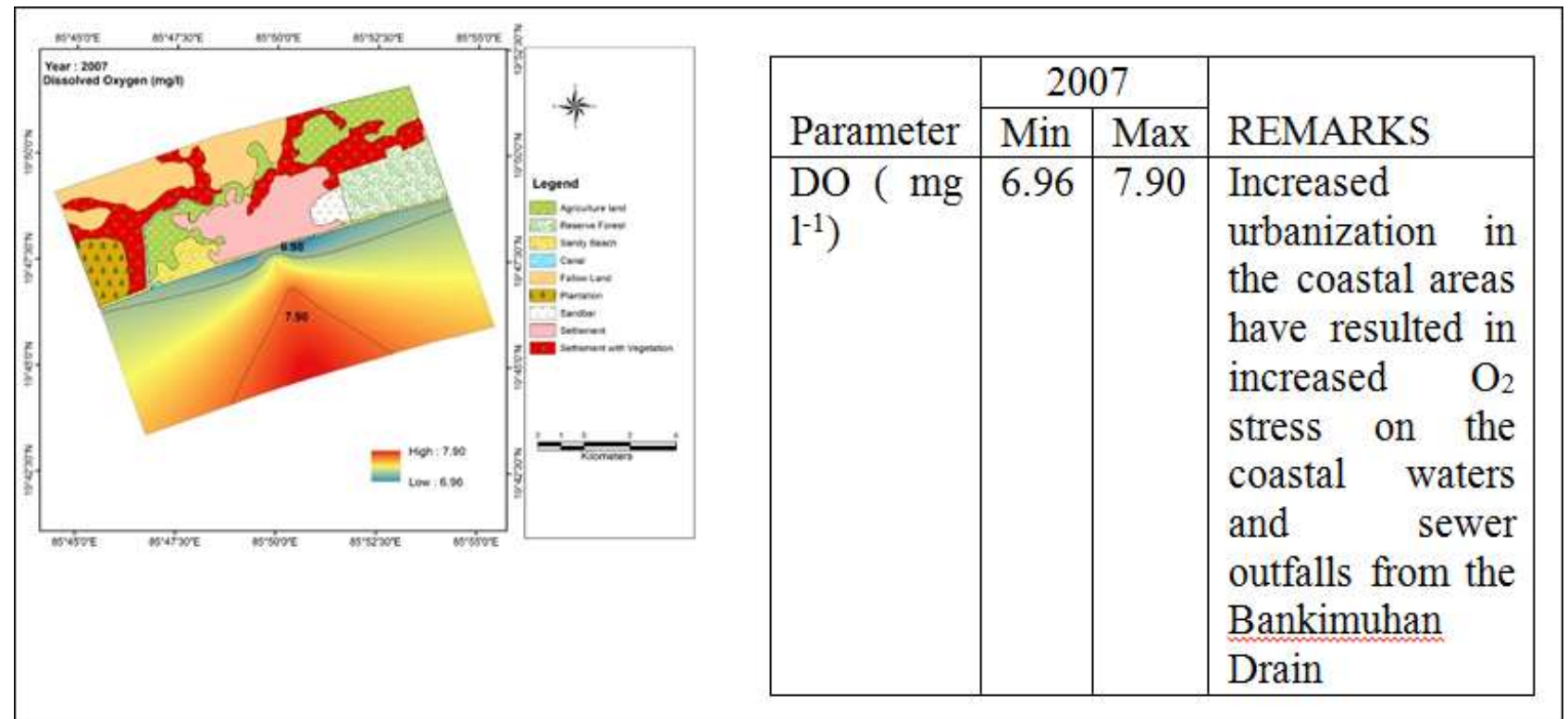

Variation in Suspended Solid Concentration (SSC)( 2007)

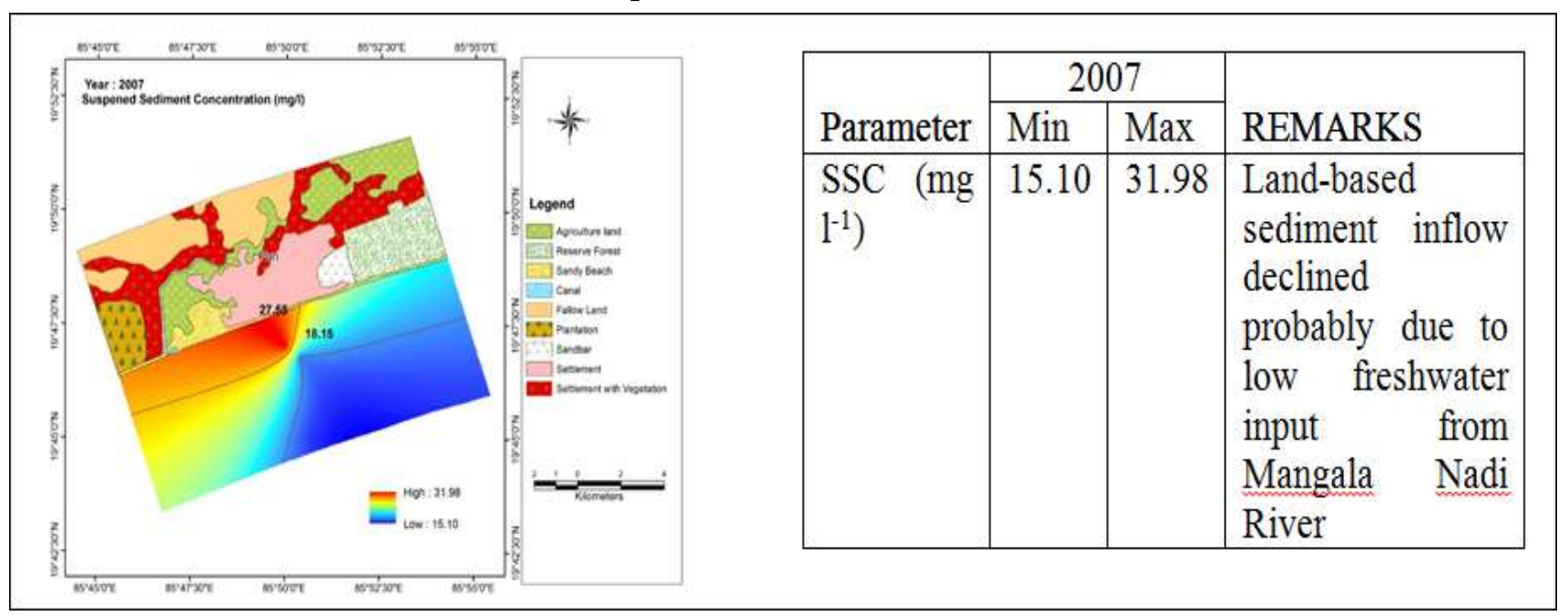

Variation in Total Nitrogen (2007)

\begin{tabular}{|c|c|c|c|c|c|}
\hline 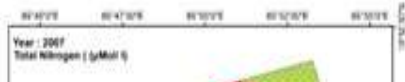 & \multirow{3}{*}{$\begin{array}{l}* \\
* \\
= \\
= \\
=\end{array}$} & \multirow[t]{2}{*}{ Parameter } & \multicolumn{2}{|c|}{2007} & \multirow[t]{2}{*}{ REMARKS } \\
\hline & & & Min & Max & \\
\hline 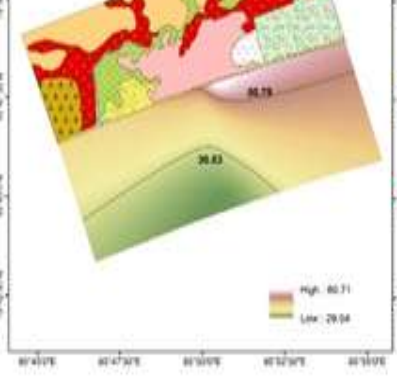 & & $\begin{array}{c}\text { Total } \\
\text { Nitrogen } \\
\left(\mu m o l 1^{-1}\right)\end{array}$ & 29.54 & 60.71 & $\begin{array}{l}\text { The high concentration is } \\
\text { due to agriculture usage } \\
\text { of fertilizers, increase of } \\
\text { usage of nitrates from } \\
\text { urea industry and } \\
\text { methods of waste } \\
\text { disposal. }\end{array}$ \\
\hline
\end{tabular}


Variation in Total Phosphorus (2007)

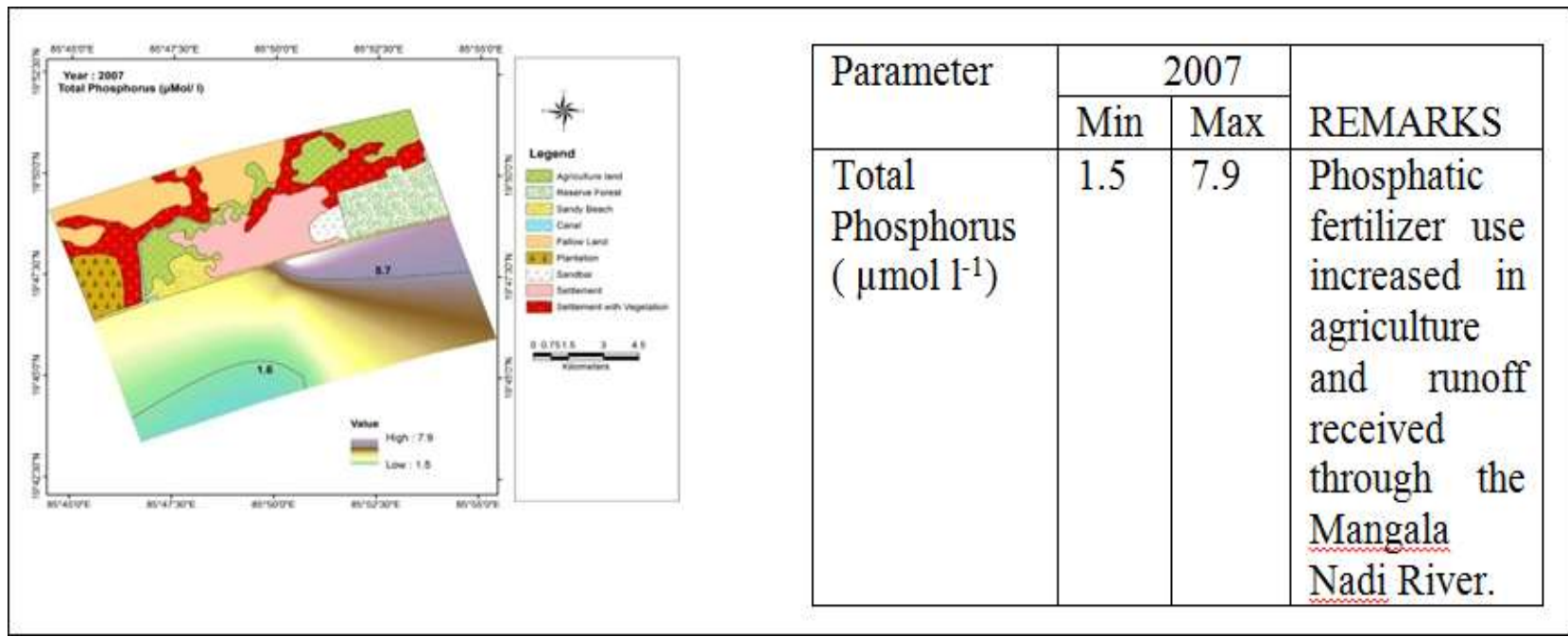

KONARK

Variation in Chlorophyll-a ( 2007)

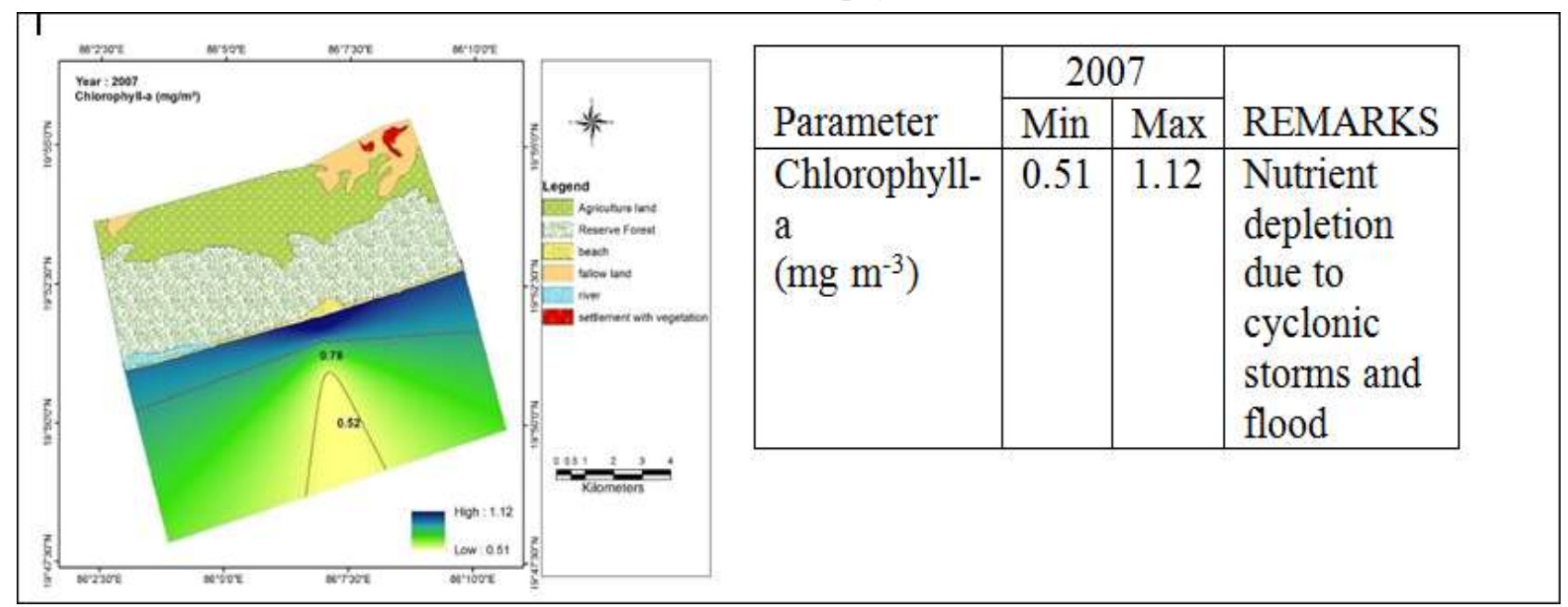

Variation in Dissolved Oxygen concentration ( 2007)

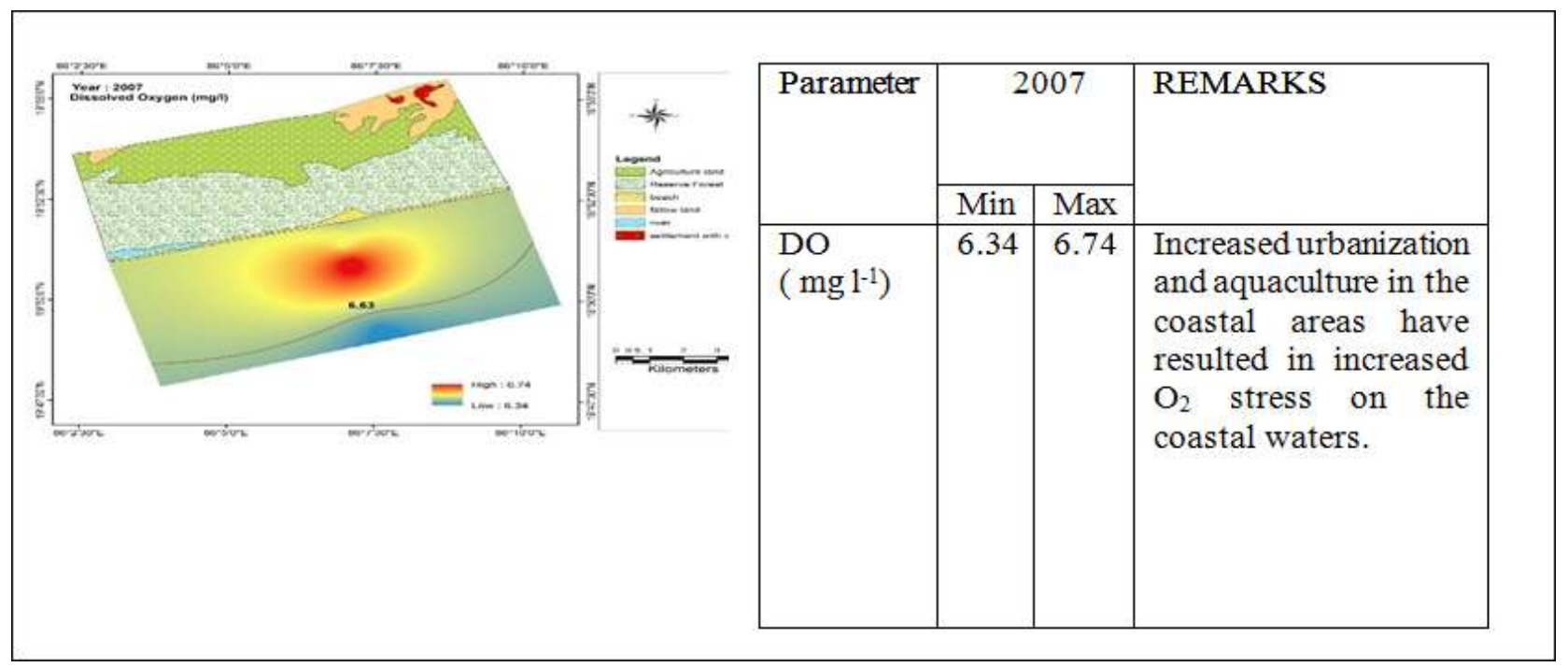




\section{COASTAL POLLUTION MANAGEMENT PLAN IN ODISHA COAST}

Variation in Suspended Solid Concentration (SSC)( 2007)

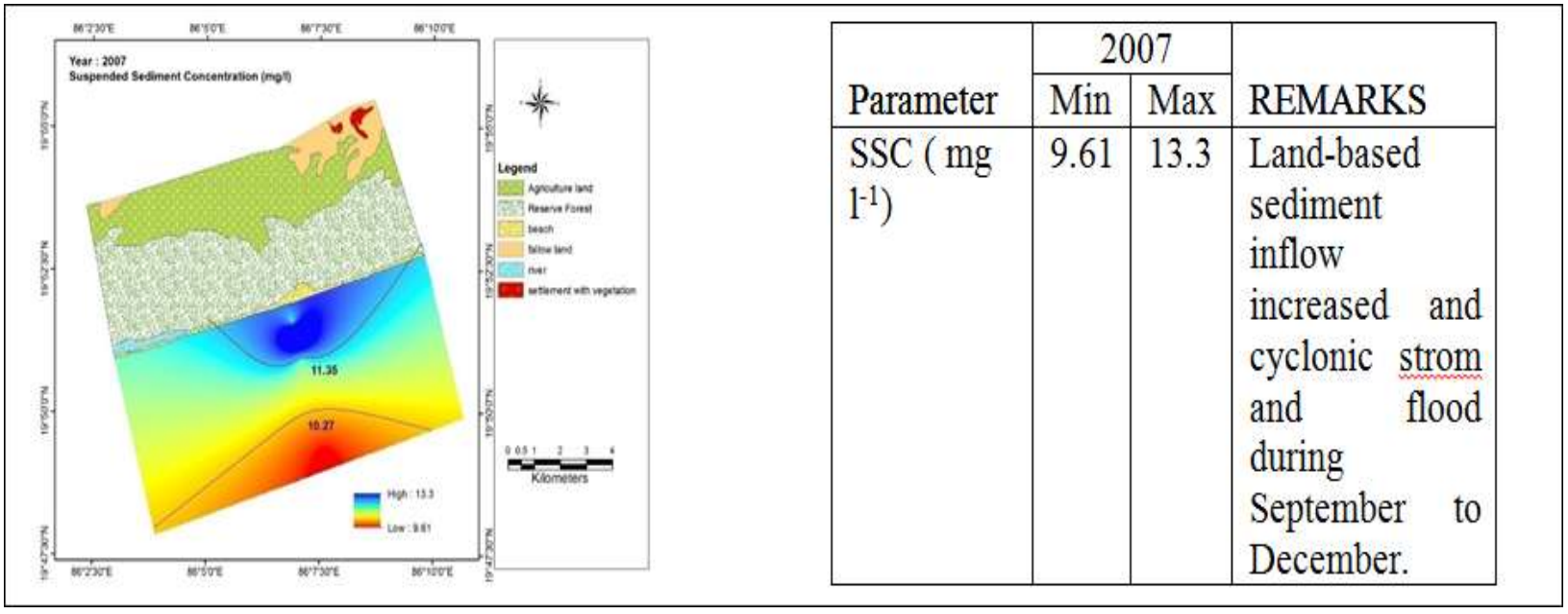

Variation in Total Nitrogen ( 2007)

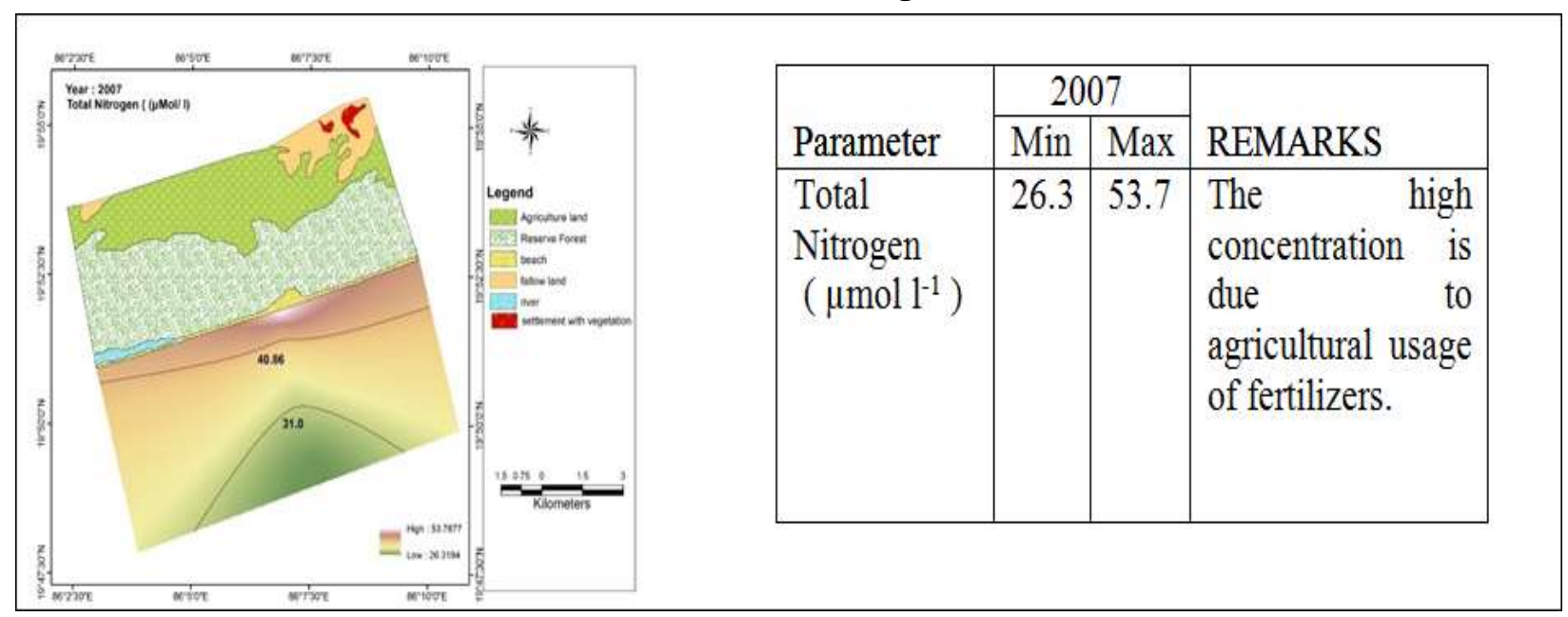

Variation in Total Phosphorus ( 2007)

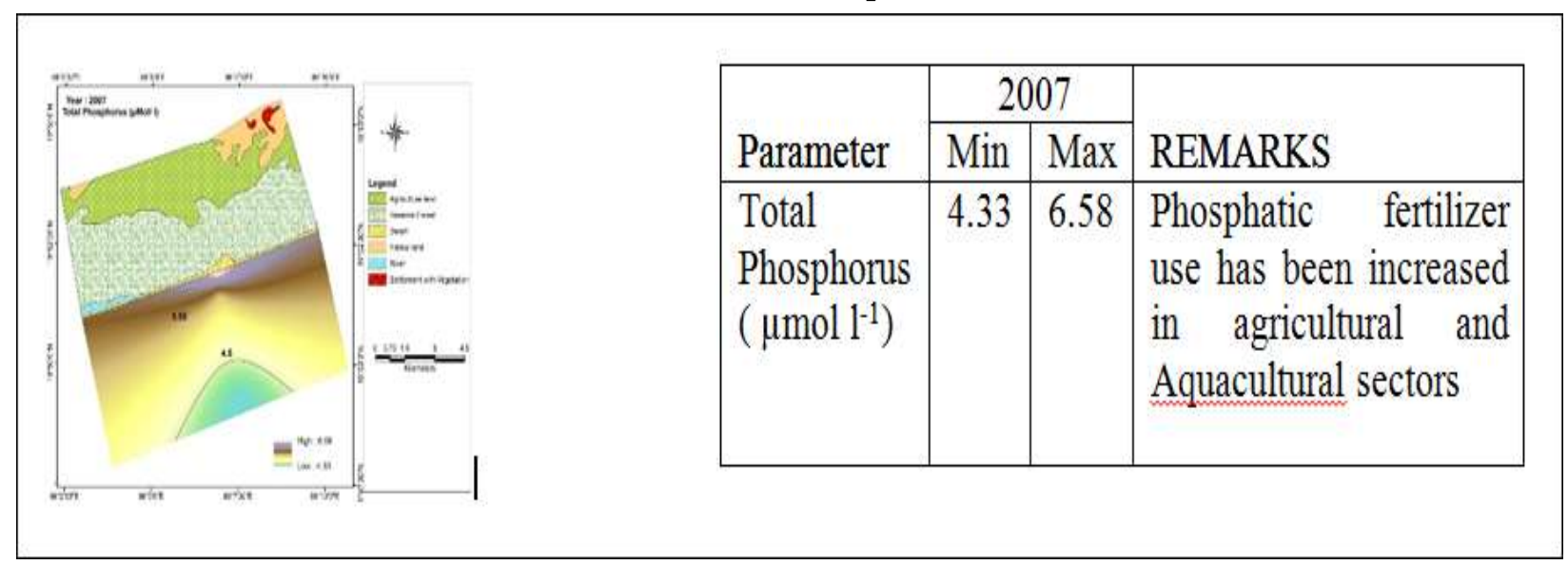

\section{CONCLUSION AND RECOMMENDATIONS}

From the GIS Based marine pollution study for the coast of Odisha it has been understood that is severely influenced by anthropogenic activities and must be monitored on a continuous basis as a "prime hotspot" for better management of these coastal waters.

From the understanding of the study the following recommendations were made:
Recommendation for Pollution Management Plan:

- Cleaning up the coastal sea will require proper management of the land.

- Pollution management will require an integrated approach which includes natural resource and land use decisions.

Published By: 
- Marine organisms being in closer chemical contact with their environment than terrestrial organisms are more vulnerable to pollution and may require closer scrutiny.

- Projects with unacceptable pollution potential should be discouraged.

- Enforcement of existing pollution regulations may be as important as writing new pieces of legislation.

- Question the type of sewage system being proposed for a coastal site.

- Discharge inland cities from looking at nearby coastal waters as sewage disposal sites (If inland cities are allowed to dump their sewage effluent in coastal waters, then strict regulations and rigorous monitoring of that discharge must be religiously enforced).

- Encourage the reclamation of sewage water.

- Require that dischargers regularly demonstrate that other alternatives are not available and or that the best possible pretreatment are being used.

- Establish comprehensive monitoring programs.

- Put a ban on coastal dumping of solid waste.

- Increase soil and water conservation practices along coasts (Encourage conservation farming techniques as terracing, minimum tillage drip irrigation, dry land farming, etc., where and when appropriate).

\section{REFERENCES}

1. Glasby.GP. what is extra, Roonwal.GS, (1995), 'Marine contamination and its outcomes' Bangalore (CURR.SCI)', Vol. sixty eight, No. 5 pp. 495-497.

2. Lam and Nina Siu-Ngan (1983), 'Spatial Interpolation methods: A review, Ingenta connect Spatial Interpolation techniques A review.mht'.

3. Mani Murali .R, Vethamony.P, Saran.A.okay. additionally, Jayakumar.S (2006) 'alternate Detection research In Coastal zone capabilities Of Goa, India with the aid of faraway Sensing',J.cutting-edge technological know-how Vol.91 pp.816.

4. Menon N.R, Katti R.J and Shetty H.\%.(1976), ' Biography of marine fouling in Mangalore waters'.

5. Muthusamy.S, Rosario Arunkumar, Naveen Raj.T, Lakshumanan.C, Jayaprakash.M (2010) 'Land Use and Land cowl changes Detection the use of Multitemporal satellite information, Cuddalore Coastal region, Se-bank Of India', global magazine Of Geomatics And Geosciences vol.1 pp.610.

6. Ouseph PP. what's more, Pillai GM.(2004), 'Costal infection along the south west bank of India, Earth framework science and herbal sources control'.pp.329-346.

7. Pillai V.okay and Vasala okay.k (1995), 'everyday types of certain metals in bivalve mollusc sunetta scripta from the Cochin waters, Indian diary of sea existence technological know-how', Vol. 24, pp. 113-one hundred fifteen.

8. Reis Selçuk (2008) 'inspecting Land Use/Land cover changes the use of far flung Sensing and GIS in Rize, North-East Turkey' pp.6188.

9. swift Theodore J. (2006), 'Water lucidity demonstrating in Lake Tahoe: Linking suspended trouble trademark to Secchi profundity, Aquatic technology',vol. sixty eight, pp. $1-15$

10. Tim Carruthers and Catherine Wazniak (2002), 'advancement of a Water high-quality Index for the Maryland Coastal Bays'.

11. Wang Xhinhao and Zhi-Yong Yin (1998), 'GIS utilising GIS to survey the relationship between land use and water pleasant at a watershed level'.

\section{AUTHORS PROFILE}

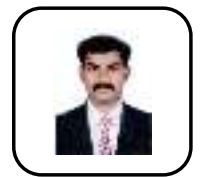

First author: Mr.D.Anburaja working as Assistant Professor in department of civil engineering at Saveetha Engineering College. He has 3 international conference papers to his credit.

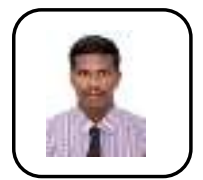

Second author: Mr.G.Sudharson working as Assistant Professor in department of civil engineering at Saveetha Engineering College. He has 5

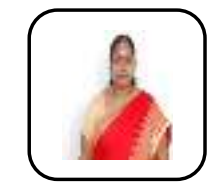

Third author: Ms.M.Kalpana working as Associate Professor in Department of Civil Engineering at Saveetha Engineering College. She has 12 years of experience. Her research include waste water treatment

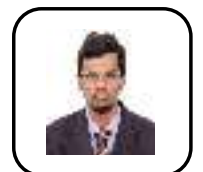

Forth author: Mr.M.G.Prathap working as Assistant Professor in department of Civil Engineering at Saveetha Engineering College. He has more research interest on waste management and constructed wetlands for waste water treatment. He has 5 research papers in Scopus Indexed journals to his credit. He has attended several national and international conferences. 